\title{
Perubahan Kualitas Bakasang Ikan Malalugis (Decapterus kurroides) Selama Penyimpanan
}

\author{
Irene V. Sani a*, Feti Fatimah a, Vanda S. Kamu a \\ aJurusan Kimia, FMIPA, Unsrat, Manado
}

\begin{tabular}{l}
\hline K A T A K U N C I \\
\hline bakasang \\
Decapterus kurroides \\
penyimpanan
\end{tabular}

\begin{abstract}
A B S T R A K
Telah dilakukan penelitian tentang kualitas bakasang ikan malalugis (Decapterus kurroides) selama penyimpanan. Adapun kajian yang dilakukan meliputi pengujian kadar air dengan metode oven, kadar lemak dengan metode soxhletasi, serta kadar protein dengan metode kjeldahl. Berdasarkan pengujian yang dilakukan didapatkan kadar air bakasang hasil penelitian semakin meningkat selama penyimpanan dari minggu pertama sampai minggu ke empat yaitu sebesar 13,5\% - 26,5\%. Kandungan protein bakasang hasil penelitian menurun selama penyimpanan dari minggu pertama sampai minggu ke empat yaitu berkisar antara 4,666\% - 3,855\%. Sedangkan kadar lemak bakasang hasil penelitian semakin menurun yaitu berkisar antara 27,23\% - 20,97\%. Hasil penelitian menunjukkan lama penyimpanan mempengaruhi kualitas bakasang.
\end{abstract}

\section{KE YW OR D S}

bakasang

Decapterus kurroides storage
A B S T R A C T

A research about the quality of the fish bakasang malalugis (Decapterus kurroides) during storage bakasang. The study was conducted on the testing of water content by oven method, fat content by soxhletasi method, and protein content by the Kjeldahl method. Based on tests found the water content of research bakasang was increasing during storage of the first week to the fourth week was equal to $13.5 \%-26.5 \%$. Protein content of research bakasang results was decreasing during storage from the first week to the fourth week in range between $4.666 \%-3.855 \%$. Fat content of bakasang research was decreasing in range between $27.23 \%-20.97 \%$. The results showed storage time affects the quality bakasang.
TERSEDIA ONLINE

09 Februari 2016

\section{Pendahuluan}

Indonesia merupakan negara kepulauan yang luas yang memiliki daratan yang melintang dari sabang sampai merauke serta perairan yang amat luas. Hal ini dapat memberikan kesempatan bagi manusia untuk memanfaatkan flora dan fauna yang terdapat pada ekosistem darat maupun laut tersebut. Sulawesi Utara dikenal sebagai salah satu provinsi penghasil ikan terbesar (BPSRI, 2012). Ikan yang dihasilkan dapat langsung dikonsumsi sebagai lauk pauk ataupun diolah menjadi produk bahan pangan lainnya.
Salah satu jenis ikan yang banyak terdapat di Sulawesi Utara adalah ikan malalugis (Decapterus kurroides). Ikan Malalugis (Decapterus kurroides, Saanin, 1984) merupakan salah satu hasil terpenting dari sumber daya perikanan dan memiliki nilai ekonomis yang tinggi karena selain dagingnya memiliki tekstur yang kompak, citarasa dari ikan ini juga banyak digemari masyarakat sehingga dapat menjadi salah satu sumber pemenuhan kebutuhan protein hewani (Prihartini, 2006). Pada umumnya proses pengolahan ikan malalugis hanya memanfaatkan dagingnya saja, sedangkan bagian lainnya yaitu jeroan bisa dimanfaatkan sebagai bahan baku bakasang.

\footnotetext{
*Corresponding author: Jurusan Kimia FMIPA UNSRAT, Jl. Kampus Unsrat, Manado, Indonesia 95115; Email address: irenesani65@yahoo.com Published by FMIPA UNSRAT (2016)
} 
Bakasang adalah salah satu produk fermentasi yang umumnya dibuat dari jeroan ikan. Pengujian kualitas bakasang diperlukan karena melihat banyaknya konsumen yang menggunakan bakasang komersial sebagai bahan pangan. Kualitas bahan pangan dipengaruhi oleh lama penyimpanan, sehingga perlu dilakukan pengujian suatu bahan pangan selama waktu penyimpanan agar konsumen mengetahui tingkat kualitas bahan pangan tersebut. Purwaningsih et al. (2013), melakukan penelitian mengenai perubahan fisiko-kimiawi yang terjadi pada bakasang ikan cakalang selama fermentasi dan penyimpanan. Sampai saat ini belum dilakukan pengujian perubahan kualitas pada bakasang ikan malalugis selama waktu penyimpanan. Pada penelitian ini dilakukan analisis kualitas bakasang dari jeroan ikan malalugis selama waktu penyimpanan.

\section{Metode}

\subsection{Material}

Bahan - bahan yang digunakan adalah jeroan (usus, hati, jantung, paru dan telur) ikan malalugis segar, jeruk nipis, garam dapur, $\mathrm{Na}_{2} \mathrm{SO}_{4}, \mathrm{CuSO}_{4}$, asam sulfat pekat, $\mathrm{NaOH} 45 \%, \mathrm{NaOH} 0,1 \mathrm{~N}$, indikator PP, asam klorida 0,1 N, aquades, Heksan.

Alat - alat yang digunakan adalah papan pengalas, alat pemotong ikan, alat pengukur waktu (stopwatch), wadah, tempat sampel uji, botol, labu erlenmeyer, alat destilat, alat-alat gelas, timbangan analitik, statif, biuret, aluminium foil, labu kjeldahl, alat soxhlet, hotplate, seperangkat alat titrasi, cawan porselin, botol serum, pipet mikro, penangas air, alat pemanas (oven), desikator, lemari asam, lemari pendingin, vortex, batang pengaduk, kertas saring, dan pipet volumetrik.

\subsection{Prosedur}

\subsubsection{Pembuatan Bakasang (Wonggo, 1985)}

Ikan malalugis segar dipisahkan bagian isi perut dari daging ikan malalugis. Jeroan (usus, hati, jantung, paru dan telur) ikan dicuci di dalam wadah. Selanjutnya ditiris dalam ayakan. Ditimbang berat jeroan kemudian diberi jeruk nipis dan garam dapur $25 \%$ dari berat jeroan. Kemudian dimasukkan ke dalam botol dan dijemur selama 10 hari (fermentasi). Setelah masa fermentasi, bakasang yang sudah ada disimpan selama empat minggu pada suhu ruang dengan keadaan sampel yang tertutup, dan setiap minggu penyimpanan (minggu 1-4) dilakukan analisis perubahan kualitas bakasang dengan menggunakan beberapa parameter uji.

\subsubsection{Uji Kadar Air (Sudarmadji et al., 1989)}

Ditimbang berat cawan terlebih dahulu, sampel sebanyak $3 \mathrm{~g}$ dimasukkan ke dalam cawan petri. Setelah itu dimasukkan ke dalam oven pada suhu $105^{\circ} \mathrm{C}$ selama 3 jam, kemudian setelah 3 jam dikeluarkan dari oven dan didinginkan dalam desikator selama 30 menit hingga mencapai suhu ruang, kemudian berat akhir ditimbang.

\subsubsection{Uji Kadar Protein dengan Metode Kjeldahl (Sudarmadji et al., 1989)}

Ditimbang $3 \mathrm{~g}$ sampel dan dimasukkan ke dalam labu kjeldhal $100 \mathrm{ml}$. Larutan ditambahkan dengan 5 g serbuk $\mathrm{Na}_{2} \mathrm{SO}_{4}, 0,2 \mathrm{~g} \mathrm{CuSO}_{4}$ dan $20 \mathrm{~mL}$ $\mathrm{H}_{2} \mathrm{SO}_{4}$ lalu dicampur. Setelah itu didestruksi, pemanas dihentikan setelah cairan menjadi jernih, didinginkan kemudian ditambahkan $100 \mathrm{~mL}$ akuades (digojoc), lalu ditambahkan larutan $\mathrm{NaOH}$ $45 \%$ sampai cairan bersifat basis (ditest dengan kertas lakmus/ warna biru). Kemudian didestilasi (mulai dari pemanasan rendah), disiapkan erlenmeyer berisi larutan $\mathrm{HCl} 0,1 \mathrm{~N}$ sebanyak $50 \mathrm{~mL}$ yang sudah diberi indikator fenoftalein $1 \%$ sebanyak 2-3 tetes, untuk menampung distilat yang keluar dari sampel (destilasi akhir setelah volume mencapai $75 \mathrm{~mL})$, Destilat $(\mathrm{HCl} 0,1 \mathrm{~N})$ dititrasi dengan larutan $\mathrm{NaOH} 0,1 \mathrm{~N}$, kemudian dicatat $\mathrm{mL}$ $\mathrm{NaOH}$ yang tercapai.

\subsubsection{Uji Kadar Lemak dengan Metode Ekstraksi Soxhlet (Sudarmadji et al., 1989)}

Ditimbang 2 g sampel bakasang yang telah dihaluskan, dikeringkan, dan dibungkus dengan kertas saring. Sampel dimasukkan ke dalam tabung ekstraksi Soxhlet. Tabung ekstraksi dipasang pada alat destilasi Soxhlet dengan pelarut heksan selama 4 jam. kemudian di soxhlet selama 4 jam. Heksan yang telah mengandung ekstrak lemak bakasang dipindahkan ke dalam erlenmeyer kemudian diekstraksi dengan metode destilasi. Hasil ekstraksi dikeringkan dalam oven $100^{\circ} \mathrm{C}$ sampai berat konstan. Berat residu dinyatakan sebagai berat lemak.

\section{Hasil dan Pembahasan}

\subsection{Pembuatan Bakasang}

Bakasang dibuat dengan bahan baku jeroan ikan malalugis dan dilakukan penambahan garam dan jeruk nipis. Garam memiliki sifat yang menghambat perkembangan dan pertumbuhan mikroorganisme perusak atau pembusuk makanan (Desrosier, 1988). Pada jeruk nipis terdapat asam sitrat yang berperan sebagai zat pemberi cita rasa dan pengawet makanan. Proses pembuatan bakasang juga melibatkan proses fermentasi.

Penambahan garam dalam fermentasi berfungsi untuk mengontrol mikroorganisme, yaitu merangsang pertumbuhan mikroorganisme yang diinginkan berperan dalam fermentasi, dan menghambat pertumbuhan mikroorganisme pembusuk dan patogen. Pada bakasang juga terdapat enzim yang berasal dari jeroan ikan. Enzim tersebut memberikan perubahan terhadap bakasang.

Menurut Fardiaz (1992), enzim yang terdapat dalam makanan dapat berasal dari bahan mentahnya atau mikroorganisme yang terdapat pada makanan tersebut. Bahan makanan seperti daging, ikan susu, buah-buahan dan biji-bijian mengandung enzim tertentu secara normal ikut aktif 
bekerja di dalam bahan tersebut. Enzim dapat menyebabkan perubahan dalam bahan pangan. Perubahan yang terjadi dapat berupa rasa, warna, bentuk, kalori, dan sifat-sifat lainnya.

\subsection{Kadar Air}

Kadar air merupakan salah satu parameter kualitas pada produk olahan bahan pangan, termasuk juga bakasang. Hasil pengujian kadar air dari bakasang dapat dilihat pada Gambar 1.

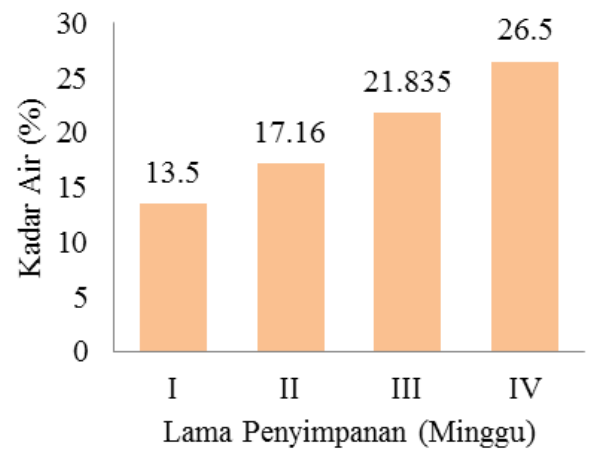

Gambar 1. Kadar Air Bakasang

Hasil analisis menunjukkan bahwa lama penyimpanan dapat memberikan pengaruh terhadap kandungan air bakasang yaitu semakin lama penyimpanan, kadar air bakasang semakin meningkat. Hal ini diduga selama penyimpanan telah terjadi penguraian senyawa organik makromolekul oleh enzime hidrolase dengan menghasilkan molekul air. Menurut Buckle et al., (1987) kondisi penyimpanan berpengaruh terhadap tinggi dan rendahnya kadar air. Semakin tinggi kadar air dalam suatu bahan pangan, daya simpan serta kualitas bahan pangan tersebut semakin rendah (Arpah, 1993).

\subsection{Kadar Protein}

Pengujian kadar protein menggunakan metode kjedahl dilakukan untuk menganalisis kadar protein kasar pada bahan makanan berdasarkan kadar nitrogen (Winarno, 1986). Hasil pengujian kadar protein pada bakasang dapat dilihat pada Gambar 2.

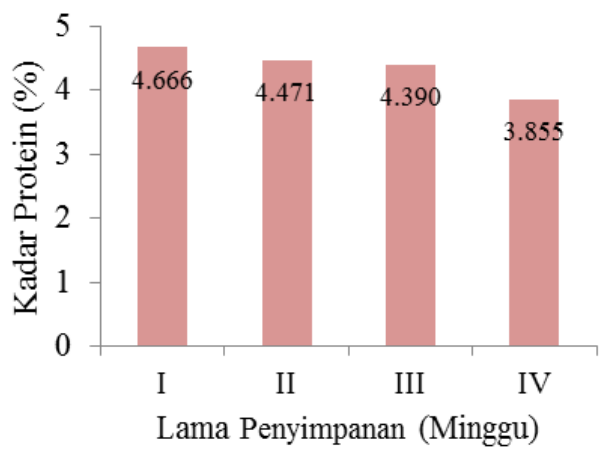

Gambar 2. Kadar Protein Bakasang
Berdasarkan data pada Gambar 2, menunjukkan bahwa faktor lama penyimpanan juga memberikan pengaruh terhadap kandungan protein bakasang. Hal tersebut disebabkan oleh adanya perubahan sifat fisiko-kimia maupun mikrobiologi, sehingga terjadi hidrolisis makromolekul protein menjadi asam- asam amino dengan pemutusan ikatan peptida dan selanjutnya peptida dan asam amino berubah menjadi senyawa yang lebih sederhana oleh enzim yang terdapat dalam jeroan atau oleh mikroba karena disimpan pada suhu kamar.

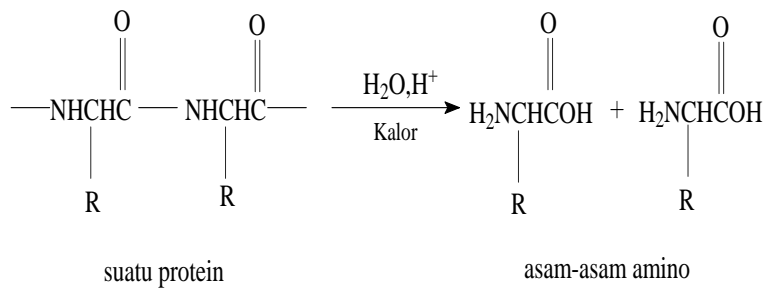

Gambar 3. Hidrolisis Protein Menghasilkan AsamAsam Amino (Lehninger, 1982).

Faktor- faktor yang berpengaruh terhadap kadar protein adalah fermentasi, pemanasan dan lama penyimpanan. Hal ini sesuai dengan pendapat Winarno (1986) yang menjelaskan bahwa semakin lama waktu fermentasi semakin banyak protein yang terpecahkan. Pada penelitian yang dilakukan Al-Bulushi et.al, (2009), menemukan bahwa proses penyimpanan terhadap produk yang telah diolah dapat menyebabkan protein dan lemak terurai menjadi komponen-komponen turunannya yang mempunyai berat molekul rendah dan berkontribusi terhadap flavor.

\subsection{Kadar Lemak}

Pada penelitian ini metode yang digunakan dalam analisis kadar lemak kasar adalah metode soxhlet (Soejono, 1990). Hasil analisis kadar lemak bakasang disajikan pada Gambar 4.

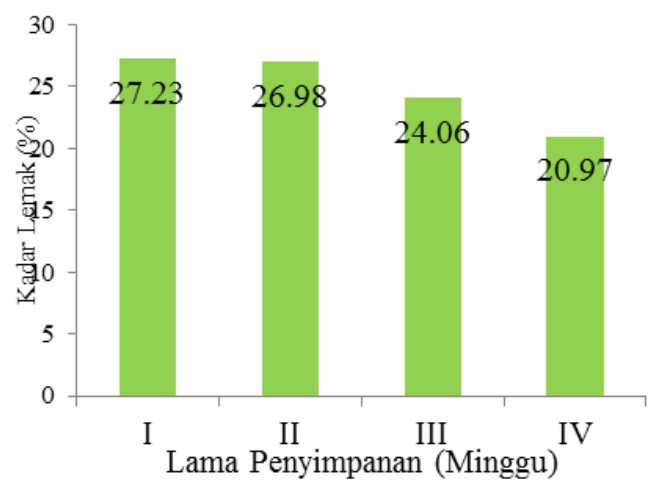

Gambar 4. Kadar Lemak Bakasang

Berdasarkan Gambar 4 kadar lemak bakasang mengalami penurunan dengan semakin lamanya penyimpanan. Menurut Winarno (1986), lemak dapat mudah rusak akibat adanya kandungan air dalam bahan pangan sehingga lemak terhidrolisis menjadi gliserol dan asam lemak bebas. Penurunan kadar lemak bakasang diduga juga disebabkan oleh 
pengaruh kadar garam yang digunakan pada saat pembuatan bakasang, karena garam dapat berperan sebagai katalis pada proses oksidasi dari lemak ikan (Hall, 1992).

\section{Kesimpulan \\ Bakasang ikan malalugis mengalami perubahan kualitas seiring dengan lama penyimpanan. Kadar air, kadar protein serta kadar lemak dari bakasang ikan malalugis berbeda dalam setiap minggu penyimpanan. Semakin lama penyimpanan, kadar air bakasang semakin meningkat sedangkan kadar protein dan kadar lemak semakin menurun.}

\section{Daftar Pustaka}

Al-Bulushi, I., S. Poole., H.C. Deeth., dan G. A. Dykes. 2009. Biogenic Amines in Fish: Roles in Intoxication, Spoilage, and Nitrosamine Formation. Journal of Food Science. 49: 369377.

Arpah, M. 1993. Pengawasan Mutu Pangan. Penerbit Tarsito, Bandung.

Badan Pusat Statistik Republik Indonesia. 2012. Produksi Perikanan Laut yang Dijual di TPI menurut Provinsi 2004-2012. Badan Pusat Statistik Republik Indonesia, Jakarta.

Buckle, K. A., A. R. Edwards, G. H. Fleet dan M. Wooton. 1987. IImu Pangan. Terjemahan $\mathrm{H}$. Purnomo dan Adiono. Jakarta : Universitas Indonesia (UI Press).
Desrosier, N. W. 1988. Teknologi Pengawetan Pangan. Edisi III. Penerjemah Muchji Mulyohardjo. Jakarta: Universitas Indonesia

Fardiaz, S. 1992. Mikrobiologi Pangan. Gramedia, Jakarta.

Lehninger, 1982. Dasar-dasar Biokimia. Jilid 1. Terjemahan M. Thenawidjaya. Erlangga, Jakarta.

Prihartini, A. 2006. Analisis Tampilan Biologis Ikan Layang (Decapterus spp) Hasil Tangkap Purse Seine yang Didaratkan di PPN Pekalongan. [TESIS]. Universitas Diponegoro, Semarang.

Purwaningsih, S., J.Sanntoso., dan G. Rahmatia. 2013. Perubahan Fisiko-Kimiawi, Mikrobiologis dan Histamin Bakasang Ikan Cakalang (Katsuwonus pelamis, Lin) Selama Fermentasi dan Penyimpanan. Jurnal Teknologi dan Industri Pangan. 24: 1-10.

Saanin, H. 1984. Taksonomi dan Kunci Identifikasi Ikan. Bina Cipta, Jakarta.

Soejono, M. 1990. Petunjuk Laboratorium Analisis dan Evaluasi Pakan. Fakultas Peternakan Universitas Gadjah Mada, Yogyakarta.

Sudarmadji, S., Horyono B.S dan Suhardi. 1989. Analisa Bahan Makanan dan Pertanian. PAU Pangan dan Gizi UGM, Yogyakarta.

Winarno, F.G. 1986. Kimia Pangan dan Gizi I. Jakarta : PT. Gramedia.

Wonggo, D. 1985. Studi Proses Perubahan Protein Pada Fermentasi Jeroan Ikan Cakalang (Katsuwonus pelamis) Pada Suhu $45^{\circ}$ C. [TESIS]. Universitas Sam Ratulangi, Manado 